\title{
TITLE:
}

\section{BOLINOPSIS RUBRIPUNCTATA N. SP., A NEW LOBATEAN CTENOPHORE FROM SETO}

$\operatorname{AUTHOR(S):~}$

Tokioka, Takasi

\section{CITATION:}

Tokioka, Takasi. BOLINOPSIS RUBRIPUNCTATA N. SP., A NEW LOBATEAN CTENOPHORE FROM SETO. PUBLICATIONS OF THE SETO MARINE BIOLOGICAL LABORATORY 1964, 12(1): 93-99

ISSUE DATE:

1964-06-30

URL:

http://hdl.handle.net/2433/175350

RIGHT: 


\title{
BOLINOPSIS RUBRIPUNCTATA N. SP., A NEW LOBATEAN CTENOPHORE FROM SETO ${ }^{1>}$
}

\author{
TAKASI TOKIOKA
}

Seto Marine Biological Laboratory

With 3 Text-figures

On the early afternoon of January 6 this year Mr. Torao YAMamoto brought me a perfect living Cyanea nozakii KIshinouye of a medium-size caught inside the wharf at the fishing port of Seto about $1 \mathrm{~km}$ east of the laboratory and told me that many ctenophores were gathered near the northwest corner of the port together with some cyaneas. In a hope to get another good specimen of Cyanea or to find out some interesting medusae, I followed him to the port by bicycle and made a close observation there. The swarm there formed was composed mainly of Bolinopsis mikado (MOSER), a significant number of Ocyropsis fusca RANG and some of Leucothea japonica KomaI, Cestum amphitrites Mertens and Beroe cucumis FABRIcius, besides a considerable amount of Noctiluca and some hydromedusae. Among those ctenophores I found two specimens of a lobatean of a moderate size which were respectively marked distinctly with scarlet lines and large bright red spots up to about 15 in number. One of them was caught by bucket and the other by polyethylene bag, and then both specimens were carried to the laboratory on foot. The former was found in a nearly perfect condition, but unfortunately the latter was torn, especially heavily on the aboral half. Thus, the examination was made chiefly on the first one.

At a glance, these specimens reminded me of Eurhamphaea vexilligera Gegenbaur that has been recorded from this vicinity and is well known by having several red spots on lappets (KOMAI and ToKIOKA, 1942). Eurhamphaea vexilligera has a pair of coloured flagellate protuberances at the aboral end of the body, its auricles are very stout and the subtentacular adradial canal enters the meridional canal at the level considerably apart from its aboral end. In the present specimens, however, the aboral flagellate protuberances are missing, the auricles are not stout, but much flattened, and the subtentacular adradial canal enters the meridional canal at its aboral end. These characteristics seem

1) Contributions from the Seto Marine Biological Laboratory, No. 411.

Publ. Seto Mar. Biol. Lab., XII (1), 1964. (Article 3) 
just to prove that this ctenophore belongs to the family Bolinopsidae, but not to Eurhamphaeidae which comprises two species in the Japanese waters: Eurhamphaea vexilligera and Kiyohimea aurita Koma and Tokioka (Koma and TokiokA, 1940). Then, there has never been described any species of Bolinopsidae with such a prominent and regular colouration. Evidently this must be a new species.

After the examination was over, it was attempted to fix the specimens with formalin, but this was not successful; only the tentacular apparates are now available as specimens. Before closing this introductory note I want to express my hearty thanks to Mr. Yамамото for his kindness in telling me of that dense aggregation of ctenophores and thus letting me have the chance to record the present new species.

\section{Bolinopsis rubripunctata $\mathrm{n}$. sp.}

The body is roughly oval in outline, $50 \mathrm{~mm}$ in the length of body proper and attains more than $60 \mathrm{~mm}$ in total length comprising lappets. The lappets are of a moderate size, their bases are approximately at the level of the middle of the whole body. When the lappets are fully extended posteriorly, the oral end of the body proper comes near the middle of the lappet length. The aboral end of the body is bluntly acute, while the oral end of the body proper is truncate and with a pair of insignificantly protruded lips (Text-fig. 2-D, 1b.). On the pharyngeal plane, it is widest roughly at the level of the oral end of the body proper, about $45 \mathrm{~mm}$ across, while it is $32 \mathrm{~mm}$ across at the level of the aboral end of the pharynx (Text-fig. 1-A). The body is slightly compressed along the tentacular axis (Text-fig. 1-B) which is about $20 \mathrm{~mm}$ across at the level of the aboral end of the pharynx. There is a very prominent aboral cleft stretching on the pharyngeal plane, this is so deep that the aboral end of the pharynx is situated at the level of aboral one-fourth or one-third of the body proper. Auricles are rather wide and flattened, the tip is bluntly pointed and falls a little distance to the oral margin. Eight meridional canals divide the body surface nearly equally (Text-fig. 2-C), although the distance between the canals is a little less between the couple of subpharyngeal canals. The subtentacular meridional canals fall into the aboral cleft just near the apical end of the body, while the subpharyngeal ones do at the level about $4 \mathrm{~mm}$ below the apical end (Text-fig. 1-A, B). The subtentacular comb rows are short, they begin at the aboral end of the meridional canal and end a little before the canal enters the auricle, there are fifty to sixty comb plates along each rib. The subpharyngeal comb rows are about two times as long as the subtentacular ones, they begin at the aboral end of the meridional canal, too, and reach near the marginal end of the lappet; there are about 120 comb plates along each rib. Lappet canals 


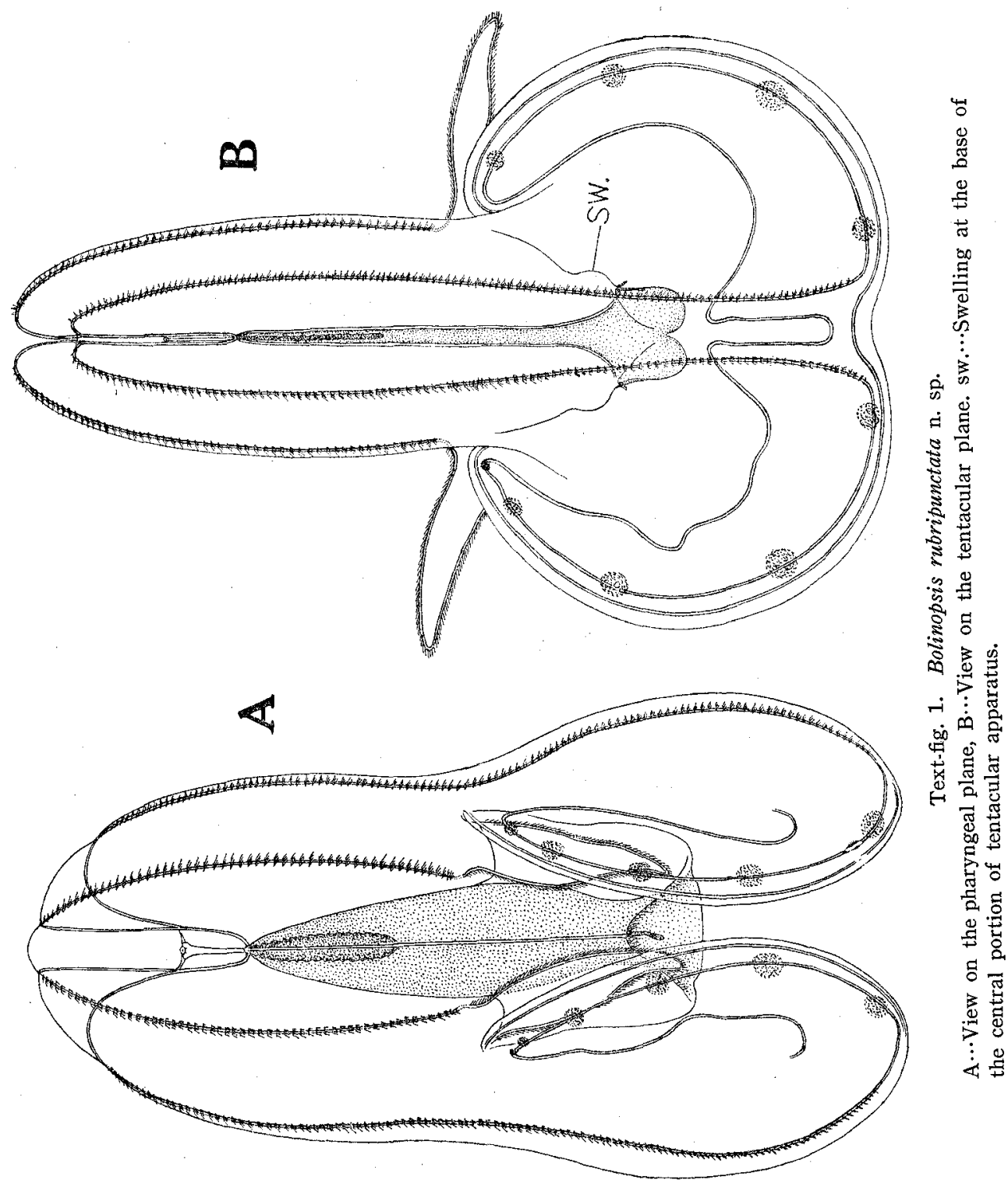


are simple as shown in the figure (Text-fig. 1-B).

The tentacular apparatus is situated at the level of the distal one-third of the oral portion extending beyond the bases of auricles (Text-fig. 2-D). It consists of the central portion and rows of fine tentacular filaments along the folds
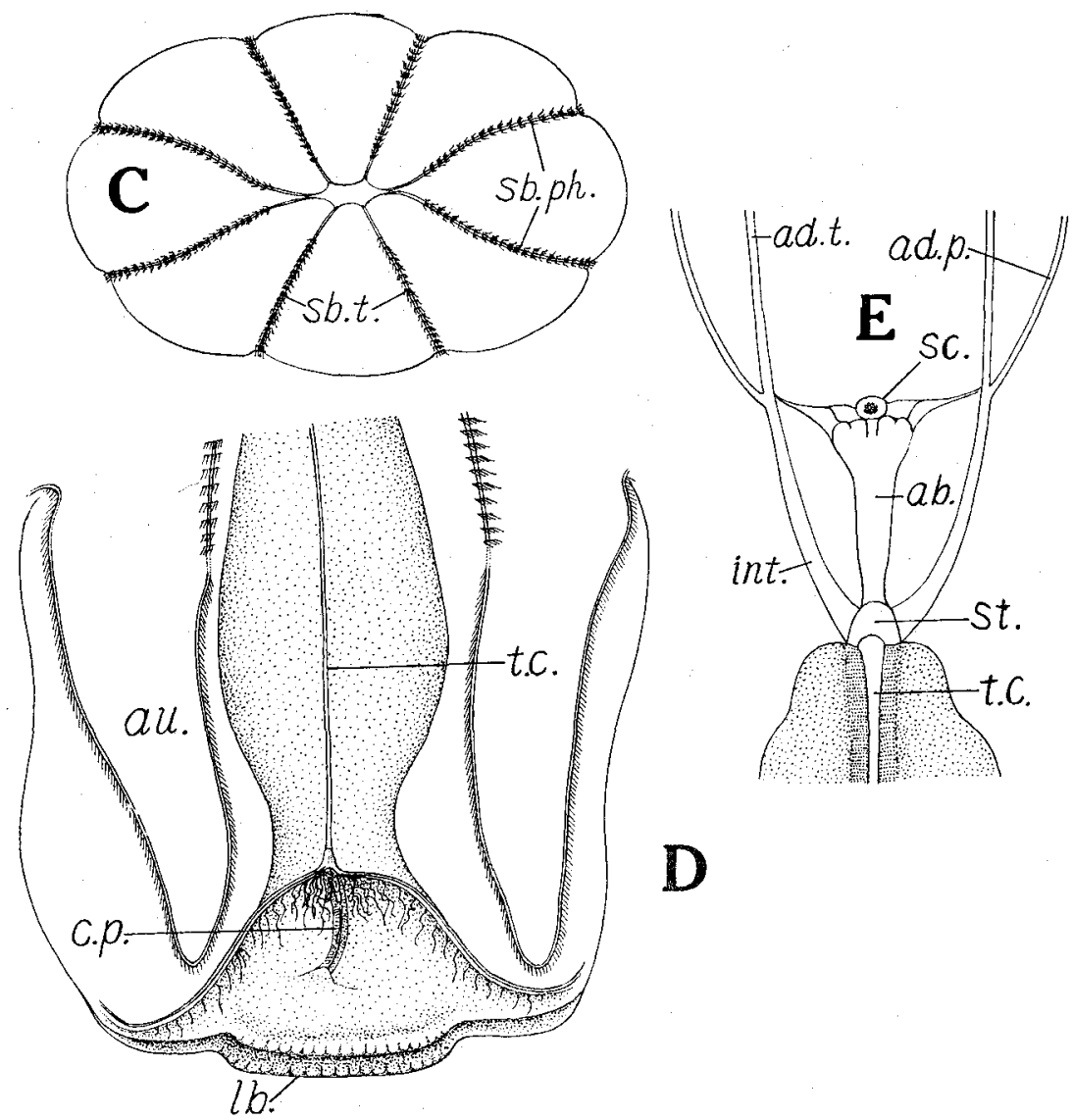

Text-fig. 2. Bolinopsis rubripunctata n. sp.

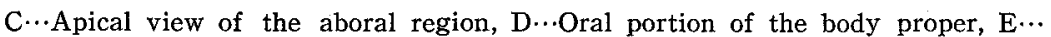

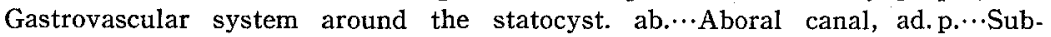
pharyngeal adradial canal, ad.t...Subtentacular adradial canal, au. $\cdots$ Auricle, c.p. ... Central portion of tentacular apparatus, int...Interradial canal, lb. $\cdots$ Lip, sb. ph. $\cdots$ Subpharyngeal meridional canal, sb.t. . Subtentacular meridional canal,

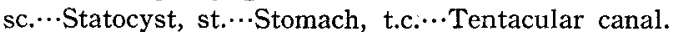

stretching along the branches of the tentacular canal; these branches begin at the proximal end of the central portion and go farther beyond respective ends of the oral aperture much elongated on the pharyngeal plane. The central portion (Text-fig. 3-F) is composed of the elongate vestigial tentacular sheath 
and the vestigial tentacular base. The former is about $4 \mathrm{~mm}$ long and lateral halves can be folded along the median line. The latter consists of two, long and short, finger-shaped protuberances or tentacle-bulbs arranged side by side and a median elongate elevation always having a remarkable constriction at the distal one-third or one-fourth. On fixation, both finger-shaped protuberances contract to oval elevations of nearly the same size (Text-fig. 3-f), and rows of tentacular filaments are represented by two filament tufts arranged one at the proximal base of each tentacle-bulb. In one of the three tentacular apparates

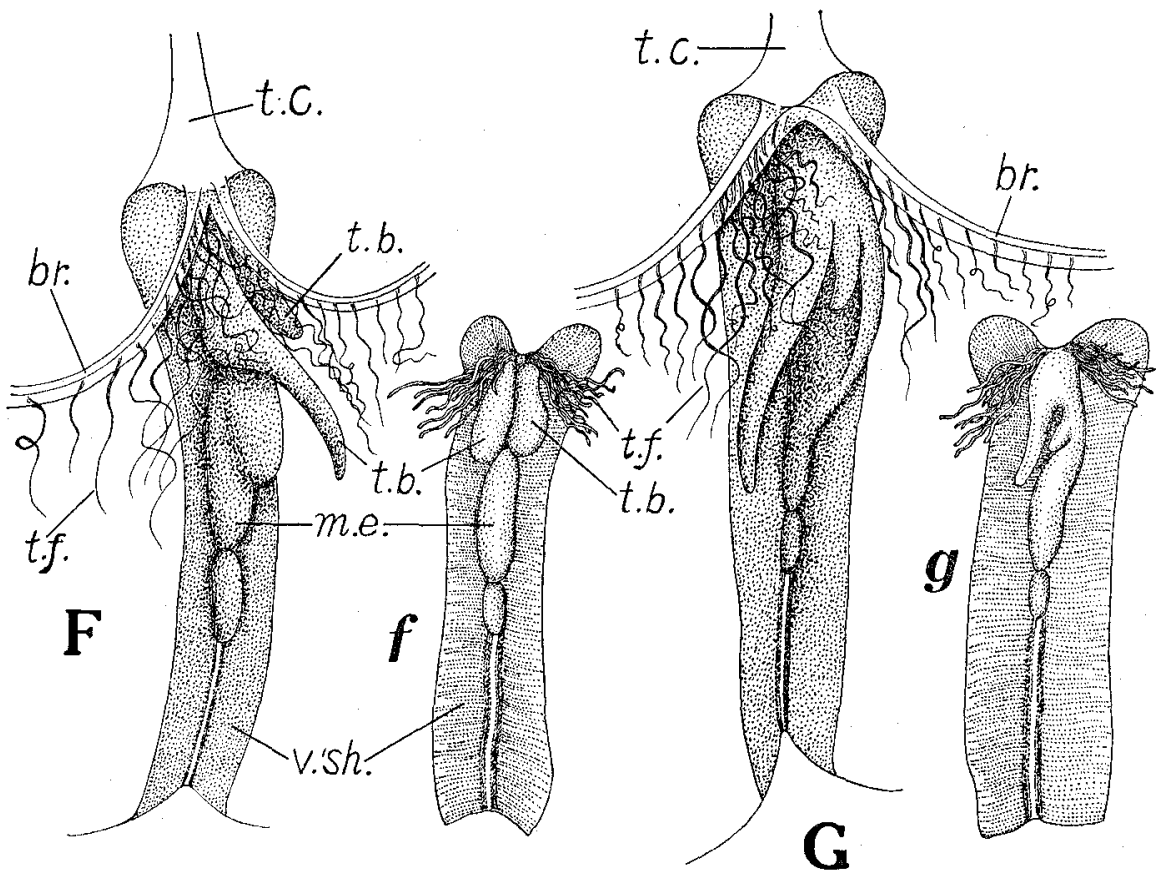

Text-fig. 3. Bolinopsis rubripunctata n. sp.

F...Tentacular apparatus of a living specimen, f $\cdots$ The same fixed in formalin, G... Malformed (?) tentacular apparatus in living state, g*..The same fixed in formalin. br. $\cdots$ Branch of tentacular canal, m.e. $\cdots$ Median elevation, t.b. $\cdots$ Tentacular bulb, t.c. $\cdots$ Tentacular canal, t.f... Tentacular filament, v.sh...Vestigial tentacular sheath.

(one on the mutilated specimen was missing), two tentacle-bulbs and the median elevation were found completely combined into a single membranous structure with two, long and short, finger-shaped lobes as shown in Text-fig. 3-G and g. Probably this is a malformed one. The triangular area surrounded by the oral margin and rows of tentacular filaments, at least the distal half of this area, might be the pharyngeal surface everted out. There is a roundish swelling of body surface at the base of the central structure of each tentacular apparatus, this can be seen clearly on Text-fig. 1-B (sw.). 
The pharynx is steadily widened towards the oral end, but narrowed again before it reaches the oral aperture (Text-fig. 1-A, 2-D). Pharyngeal folds are found in the aboral one-third of the pharynx. The four interradial canals are issued directly from the stomach (st.), and they are divided into adradial canals at the level of the oral one-third of the distance between the stomach and the apical end of the body; the statocyst is situated at this level, too. The distance between the interradial canals is much less on the tentacular plane than on the pharyngeal plane. Interradial and adradial canals of each half body are running on the same pharyngeal plane.

Colouration: The meridional canals along comb rows, the lappet canals and the canals fringing auricles are all coloured reddish orange. The aboral onethird of the pharynx is faintly tinted orange. The central portion of the tentacular apparatus is also coloured reddish orange. In addition to these, there are four to six large bright reddish orange round spots along the periphery on each side of respective lappets. These coloured spots are arranged along the first branch of the loop formed by the extension of subpharyngeal meridional canal (Text-fig. 1-A, B), one or two spots near the bending point of the loop are generally smaller than others. Other parts of the body are mostly colourless and quite transparent, except for the pharynx which is faintly milky whitish.

Remarks: The general appearance of the present specimens described here resembles very closely those of Bolinopsis vitrea (AGASSIz) from the warm waters of the Atlantic and the Mediterranean Sea and Bolinopsis mikado (MOSER) from the Japanese waters in the Pacific. Especially B. mikado is closely related with the present specimens in the relative size of the lappet and the distribution of comb plates along the subpharyngeal meridional canal. However, the auricles seem to be a little shorter in the present specimens than in B. mikado in which the end of auricles reaches somewhat beyond the margin of mouth. B. vitrea seems to be provided with somewhat larger lappets. Anyhow, the most prominent characteristic of the present specimens must be their remarkable colouration. Of other species of Bolinopsis, B. mikado is generally transparent and almost colourless; only the canals are rosy when living as stated by KomaI (1918, p. 455). In B. paragaster RALPH from Cook Strait, New Zealand, "except for the deep red-brown pigment of the stomodeum and the light red globules in the canals (all the canals, but especially the paragastric canals and the tentacular canals) the specimens are transparent and colourless" (RALPH, 1950, p. 5). In B. vitrea, "the gelatinous substance is either transparent or diffusely tinged by a faint pink. The peripheral chymiferous tubes are of a more decided pink and in the lappets these tubes often display masses of intense pink color, probably due to products of digestion or excretion (p. 23). Some individuals being transparent and colourless, while others exhibit large, deep-colored masses of pink pigment in their chymiferous tubes, or pink diffused through their gelations substance (p. 24)" (MAYER, 1912). 
The last descriptions about $B$. vitrea seem to afford the following two possibilities. One is that the present specimens might be identical with $B$. vitrea and the other is that the present specimens might be nothing but the coloured variants of $B$. mikado. As to the first possibility it must be noted that the colour shade differs distinctly between the two and that the regularly arranged colour spots in the present specimens are not formed inside the canal, although they are never formed apart from the canal. As to the last possibility, there has never been reported any occurrence of individuals showing intermediate pigmentation, and this seems to object against this supposition. The peculiar pigmentation found in the present specimens seems therefore to be a unique one as the pigmentation is so in Eurhamphaea vexilligera and thus of a specific significance. The circumboreal species Bolinopsis infundibulum (MúlLER) is also known from the northern North Pacific, under the names of Bolina septentrionalis Mertens and Bolina microptera A. Agassiz on the western coast of North America (Torrey, 1904). This species is, however, a cool or cold water form and is considerably larger than $B$. vitrea and provided with much fewer, less than 50, comb-plates along the ribs (KRUMBACH, 1927). Moreover, this is generally quite colourless. Thus, this species may be put aside in discussing the identification of the present specimens. For these reasons, I want to treat the present specimens as a new species and name it Bolinopsis rubripunctata after their characteristic pigmentation.

\section{REFERENCES}

Chun, C. (1880): Die Ctenophoren des Golfes von Neapel. Fauna u. Flora Golf. Neapel, Monogr. 1.

KOMAI, T. (1918): On ctenophores of the neighbourhood of Misaki. Annot. Zool. Japon., Vol. 9, Part 4, pp. 451-474, Pl. VII.

KomaI, T. and T. TokiokA (1940): Kiyohimea aurita, n. gen., n. sp., type of a new family of lobate Ctenophora. Annot. Zool. Japon., Vol. 19, No. 1, pp. 43-46, 3 text-figs.

KomaI, T. and T. TokiokA (1942): Three remarkable ctenophores from the Japanese seas. Annot. Zool. Japon., Vol. 21, No. 3, pp. 144-151, 6 text-figs.

Krumbach, Th. (1927) : Ctenophora in : Die Tierwelt der Nord- und Ostsee, Teil III f, 50 pp., 27 text-figs.

Mayer, A. G. (1912): Ctenophores of the Atlantic coast of North America. Carnegie Institution of Washington Publ., No. 162, 58 pp., 17 pls., 12 text-figs.

Ralph, P. M. (1950): New Zealand coelenterates. Ctenophores from Cook Strait. Zool. Pubi. Victoria Univ. Coll,, No. 3, 11 pp., 4 text-figs.

Torrey, H. B. (1904): The ctenophores of the San Diego region. Univ. California Publ. Zool., Vol. 2, No. 2, pp. 45-50, 1 pl. 